\title{
The topoisomerase inhibitors camptothecin and etoposide induce a CD95-independent apoptosis of activated peripheral lymphocytes
}

\author{
C Ferraro ${ }^{1}$, L Quemeneur ${ }^{1}$, S Fournel ${ }^{1,3}$, A-F Prigent ${ }^{2}$, \\ J-P Revillard ${ }^{1}$ and $\mathrm{N}$ Bonnefoy-Berard ${ }^{\star, 1}$ \\ ${ }^{1}$ Laboratory of Immunology, INSERM U503 UCBL, Hôpital E. Herriot, 69437 \\ Lyon, France \\ 2 Laboratory of Biochemistry and Pharmacology, INSERM U352, INSA-Lyon, \\ 69621 Villeurbanne Cedex, France \\ 3 Current address: INSERM U395, BP 3028CHU, Purpan 31024, Toulouse \\ Cedex, France \\ * Corresponding author: N Bonnefoy-Berard PhD, INSERM U503, Hôpital E. \\ Herriot, 69437 Lyon, cedex 03, France. \\ Tel: 33472110177 , Fax: 33472330044
}

Received 22.3.99; revised 23.8.99; accepted 30.8.99

Edited by S Martin

\begin{abstract}
The effect of etoposide and camptothecin, two topoisomerase inhibitors directed against topoisomerases II and I, respectively, was evaluated on human peripheral blood lymphocytes. Etoposide and camptothecin induced apoptosis of mitogen-activated but not resting $\mathrm{CD}^{+}$and $\mathrm{CD8}^{+} \mathrm{T}^{-}$ lymphocytes. Cell sensitivity to these agents required $G_{1}$ to S-phase transition of the cell cycle. Conversely, daunorubicin, an intercalating agent and topoisomerase Il inhibitor, induced apoptosis of both resting and activated lymphocytes. Although etoposide and camptothecin induced CD95-ligand mRNA expression, drug-induced apoptosis of activated human lymphocytes was not inhibited by CD95 antagonists. Drug-induced cell death was also not inhibited by p55 TNFR-lg fusion protein. Activation of the caspases cascade was suggested by the partial inhibitory effect of the tripeptide ZVAD-fmk and documented by activation of caspase 3 . Finally etoposide and camptothecin induced a rapid production of ceramide in activated but not resting peripheral blood lymphocytes, suggesting that ceramide might initiate the signaling apoptotic cascade in sensitive cells. Cell Death and Differentiation (2000) 7, 197-206.
\end{abstract}

Keywords: apoptosis; caspase; camptothecin; ceramide; etoposide; peripheral blood lymphocytes

Abbreviations: CPT, camptothecin; CD95-L CD95 ligand; CsA, cyclosporin A; ConA, concanavalin A, ETO, etoposide; DNR, daunorubicin; PARP polyADPribose polymerase; PBL, peripheral blood lymphocytes; PHA, phytohemagglutinin; PMA, phorbol 12myristate acetate; RPM, rapamycin; SEB, Staphylococcal enterotoxin B; TNF, tumor necrosis factor; TNFR tumor necrosis factor receptor; $\mathrm{mAb}$, monoclonal antibody

\section{Introduction}

Topoisomerases are enzymes that modulate superhelicoïdal density of DNA and act by introducing single (type I) or double (type II) DNA breaks. These enzymes are involved in DNA repair, replication, transcription, and chromosome segregation during mitosis. The topopoisomerase inhibitors CPT and ETO, which inhibit topoisomerase I and II, respectively, stabilize the DNA-single or -double breaks. ${ }^{1,2}$ The effect of these two drugs has been widely studied on cell lines stemmed from solid tumors (e.g. osteoblastoma, ${ }^{3}$ hepatoblastoma, ${ }^{4}$ colon carcinoma ${ }^{5}$ neuroblastoma ${ }^{6}$ or glioma ${ }^{7}$ ), or hematopoietic cell lines such as promyelocytic, ${ }^{8}$ monocytic ${ }^{9}$ or lymphoid $\left(\mathrm{CEM}^{10}\right.$ and Jurkat $\left.{ }^{11,12}\right)$ leukemia cell lines. Topoisomerase inhibitors can induce either inhibition of proliferation or apoptosis, depending on the cell line tested. CPT derivatives are clinically active against human cancers, such as small cell lung cancer, colon or ovarian carcinoma, whereas ETO is used in various leukemias. ${ }^{13,14}$

The apoptotic signaling pathways initiated by chemotherapeutic agents have been recently investigated and evidence for the involvement of the CD95/CD95-L pathway in drug-induced apoptosis has been reported. Indeed doxorubicin increased CD95-L mRNA expression and induced apoptosis in CEM, Jurkat or neuroblastoma cells. In these cells, cell death was inhibited by blocking $\mathrm{F}\left(\mathrm{ab} \mathrm{b}^{\prime}\right)_{2}$ anti-CD95. ${ }^{6,15}$ Similar results were showed by Müller et $a A^{4}$ in hepatoma cells treated by bleomycin or methotrexate, and using the antagonist Fas-Fc molecule Kasibhatla et al ${ }^{12}$ showed that the chimeric protein partially blocked cell death induced by teniposide in Jurkat cells or by ETO in the murine T cell hybridoma 2B4. Moreover a cross-resistance toward doxorubicin and agonistic CD95 mAb was also demonstrated in human myeloma cell line RPMI $8226^{10}$ or in Jurkat ${ }^{15}$ and CEM cell lines. ${ }^{10,15}$ More recently chemotherapeutic agents such as doxorubicin, ETO and teniposide were shown to induce a rapid up-regulation of CD95-L via the activation of the SAPK/JNK pathway. ${ }^{12,16}$ However these results remain controversial ${ }^{17}$ and the observation that some Fas-resistant cell lines undergo apoptosis after treatment with ETO and doxorubicin ${ }^{11,18,19}$ suggested that in addition to the CD95/CD95-L pathway other mechanisms may be involved in drug-induced apoptosis.

Generation of ceramide from sphingomyelin has been implicated in the signaling pathway of cells undergoing apoptosis in response to a variety of stress stimuli. In addition to TNF $\alpha, C D 95-\mathrm{L}$, heat shock, ultraviolet light, oxidative stress, ${ }^{20-24}$ many chemotherapeutic agents such as cytosine arabinoside, vincristine, DNR, thymidilate synthase inhibitors and ionizing radiations have been shown to cause accumulation of ceramides. ${ }^{24-31}$

In contrast with numerous studies performed on cell lines, the effects of chemotherapeutic agents on normal 
lymphocytes have deserved little investigation so far. Administration of these agents could lead to a modulation of $\mathrm{T}$ cell response toward tumor cells with immunosuppressive side-effects. A better knowledge of their action on peripheral lymphocytes may lead to the design of new molecules or new regimens in order to improve the selectivity of tumoricidal versus immunosuppressive effects. In the present study we addressed the capacity of ETO and CPT to induce apoptosis of peripheral blood lymphocytes. We asked whether sensitivity of PBL to ETO and CPT depends on mitogenic activation, and we investigated processes involved in the apoptotic signaling.

\section{Results}

\section{Etoposide and Camptothecin induce apoptosis of activated but not resting peripheral blood lymphocytes}

Since ETO and CPT were previously reported to inhibit the proliferation of $T$ cell lines such as Jurkat, CEM, L1210 and MOLT-4, ${ }^{1,2,32}$ we have investigated whether ETO and CPT would also affect proliferation of PBL activated by different mitogens. As shown in Figure 1, when PBL were activated for 3 days in the presence of PHA and then incubated with ETO and CPT, a dose dependent inhibition of proliferation was observed. Maximal inhibitory effect was observed with 2 and $0.1 \mu \mathrm{M}$ of ETO and CPT, respectively. Since inhibition of proliferation could reflect induction of cell death, we measured apoptosis induced by these drugs. Resting PBL, or 3 day-PHA blasts, were incubated for $24 \mathrm{~h}$ with ETO and CPT at concentrations ranging from $2 \mathrm{nM}-$ $10 \mu \mathrm{M}$ and $1 \mathrm{nM}-10 \mu \mathrm{M}$, respectively and the percentage of apoptotic cells was determined by fluorescence microscopy after Hoechst 33342 staining. The percentage of apoptotic cells among PHA-activated PBL increased in a dose-dependent manner in the presence of ETO and CPT but no apoptosis was seen in non-activated cells. Under the same conditions another chemotherapeutic agent, DNR which acts both as DNA intercalating agent and topoisomerase II inhibitor, induced apoptosis of both resting and activated $\mathrm{PBL}$ in the same range of concentrations (2 nM$2 \mu \mathrm{M}$ ) (Figure 1). Apoptosis of PHA-activated but not resting PBL with ETO or CPT was confirmed by the decrease of
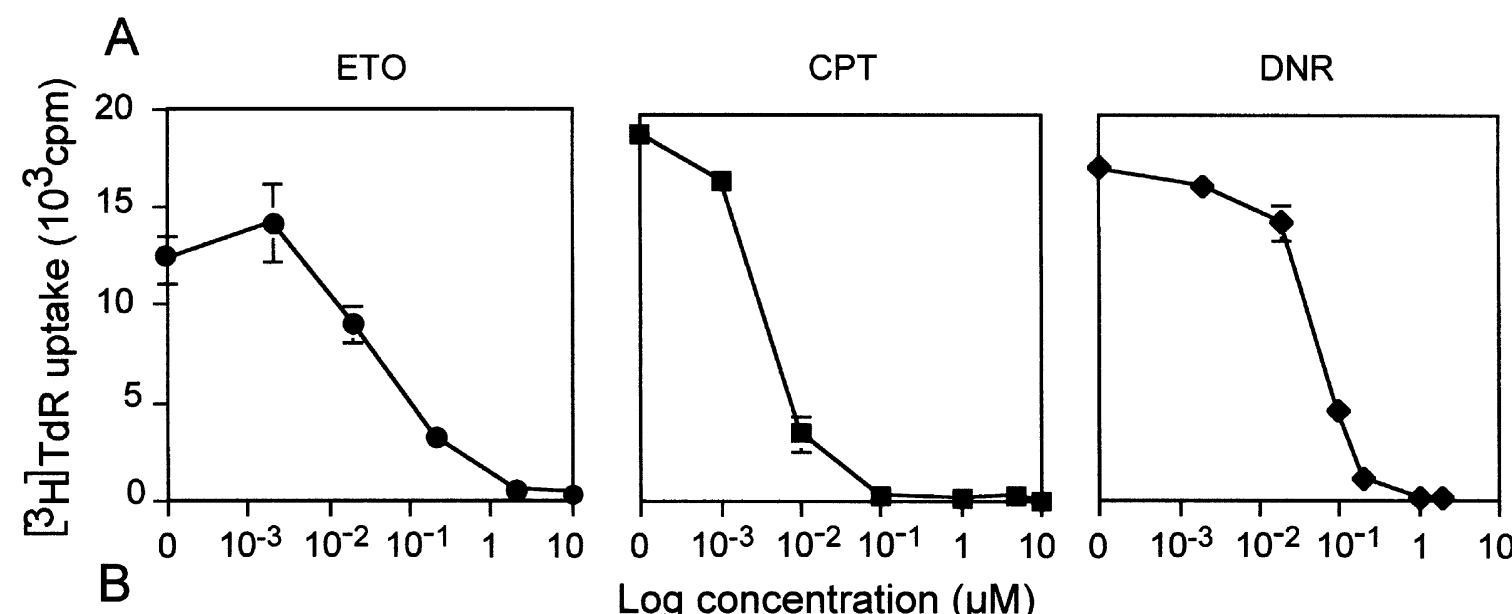

Log concentration $(\mu \mathrm{M})$
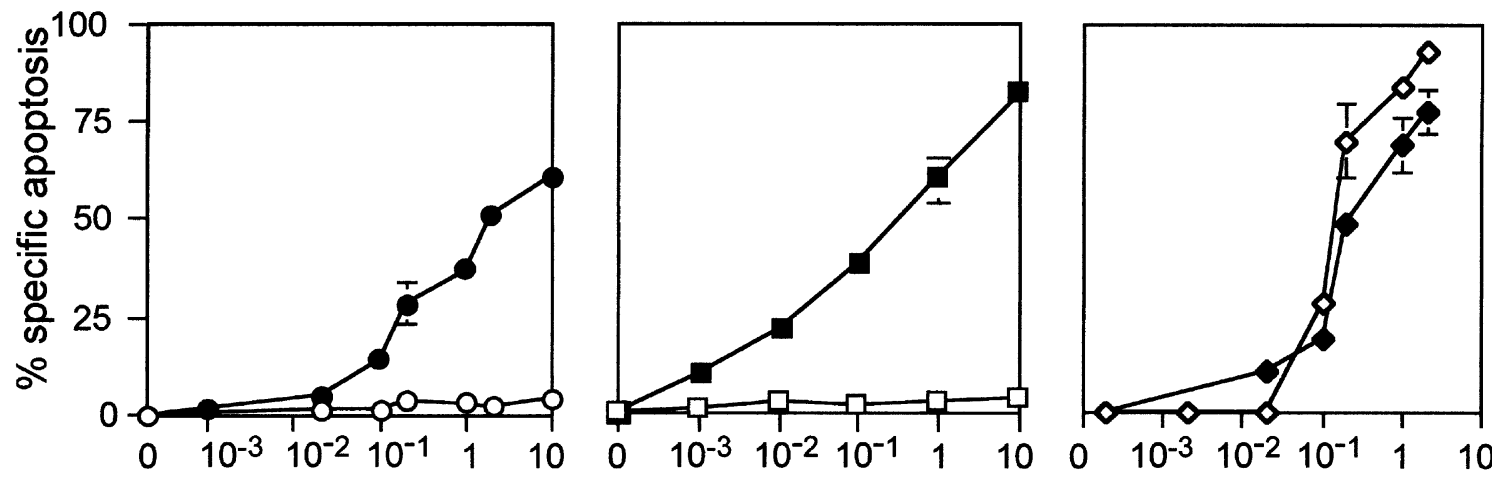

Log concentration $(\mu \mathrm{M})$

Figure 1 Effect of ETO, CPT and DNR on resting and activated PBL. PBL were cultured for 3 days with PHA ( $5 \mu \mathrm{g} / \mathrm{ml}$, closed symbols) or without PHA (open symbols). Dead cells were removed and medium, ETO, CPT or DNR were added at indicated concentrations. (A) $\left[{ }^{3} \mathrm{H}\right] \mathrm{TdR}(0.5 \mu \mathrm{Ci} /$ well) was added after $16 \mathrm{~h}$ of treatment and cells were collected $8 \mathrm{~h}$ later. Values are the mean \pm S.E.M. of four independent experiments (B) Apoptosis was determined by fluorescence microscopy after staining with Hoechst 33342 after $20 \mathrm{~h}$ of treatment. Results are expressed as percentage of specific apoptosis and values are the mean \pm S.E.M. of four independent experiments 
mitochondrial transmembrane potential $(\Delta \Psi \mathrm{m})$, measured by staining with $\mathrm{DiOC}_{6}(3)$ and by the externalization of phosphatidylserine measured by annexin $\mathrm{V}$ binding (data not shown). Activation-dependent apoptosis was also observed when PBL were stimulated with Con A, SEB, PMA plus ionomycin, immobilized or soluble OKT3 (Table 1). Incubation of 3 day-PHA blasts with ETO or CPT at $2 \mu \mathrm{M}$ and $1 \mu \mathrm{M}$ respectively (concentrations which induced $50 \%$ of apoptosis), indicated that the number of apoptotic cells increased rapidly to reach a maximum after $15 \mathrm{~h}$ of exposure to the drugs (Figure 2). Double fluorescence analysis demonstrated that both $\mathrm{CD}^{+} / \mathrm{AnnexinV}^{+}$and $\mathrm{CD8}^{+} / \mathrm{AnnexinV}^{+}$populations increased after $20 \mathrm{~h}$-incubation with ETO or CPT (Figure 3).

\section{Sensitivity to Etoposide and Camptothecin- induced apoptosis requires G1 to S-phase transition}

Because ETO and CPT are topoisomerase inhibitors and since only activated PBL were susceptible to apoptosis, we hypothesized that cells might need to be cycling in order to be sensitive to ETO and CPT-mediated apoptosis. In order to test this hypothesis we used aphidicolin, a DNA synthesis inhibitor that accumulates cells in late $\mathrm{G} 1$, or the immunosuppressive agents CsA, FK506 and RPM, which interfere with IL-2 gene transcription (CsA and FK506 ${ }^{33}$ ) or IL-2 signaling $\left(\mathrm{RPM}^{34}\right)$, and subsequently inhibit proliferative response of $\mathrm{PHA}$-activated $\mathrm{PBL}$ by blocking the progression from $\mathrm{G} 1$ to $\mathrm{S}$-phase of the cell cycle. Addition of aphidicolin $(125 \mathrm{ng} / \mathrm{ml})$, CsA $(250 \mathrm{ng} / \mathrm{ml})$, FK506 (10 nM) or RPM (60 nM) during the 3-day activation period with PHA did not inhibit CD25 expression but reduced cellular proliferation by $60 \%$ and markedly reduced ETO- and CPT-mediated apoptosis (Figure 4A). In contrast addition of either CsA, FK506 or RPM to activated PBL just $4 \mathrm{~h}$ before treatment with ETO or CPT did not decrease the percentage of apoptotic cells (Figure 4B). Finally addition of IL-2 to lymphocytes culture in presence of

Table 1 ETO and CPT-induced apoptosis of PBL activated by different mitogens ${ }^{\mathrm{a}}$

\begin{tabular}{|c|c|c|c|}
\hline \multirow[b]{2}{*}{ Stimulant } & \multirow{2}{*}{$\begin{array}{c}{\left[{ }^{3} \mathrm{H}\right] \mathrm{Tdr}} \\
\text { incorporation } \\
\left(10^{3} \text { c.p.m. }\right)\end{array}$} & \multicolumn{2}{|c|}{$\%$ specific apoptosis } \\
\hline & & ETO & CPT \\
\hline none & $0.06 \pm 0.01$ & $2.6 \pm 1.4$ & $1 \pm 0.5$ \\
\hline PHA $(5 \mu \mathrm{g} / \mathrm{ml})$ & $18.3 \pm 1.5$ & $47.5 \pm 2.0$ & $51 \pm 2.7$ \\
\hline PMA (10 ng/ml) & $0.9 \pm 0.3$ & $15.5 \pm 2.9$ & $26.1 \pm 2.9$ \\
\hline $\begin{array}{l}\text { PMA-ionomycin } \\
(0.5 \mu \mathrm{g} / \mathrm{ml})\end{array}$ & $14.7 \pm 1.0$ & $43.9 \pm 7.0$ & $52.8 \pm 7.7$ \\
\hline ConA $(10 \mu \mathrm{g} / \mathrm{ml})$ & $6.9 \pm 0.5$ & $27.7 \pm 2.7$ & $31.5 \pm 3.2$ \\
\hline SEB $(50 \mathrm{ng} / \mathrm{ml})$ & $4.0 \pm 0.5$ & $26.8 \pm 6.6$ & $22.5 \pm 3.3$ \\
\hline iOKT3 $(10 \mu \mathrm{g} / \mathrm{ml})$ & $2.7 \pm 0.6$ & $29.8 \pm 7.1$ & $29.9 \pm 7.9$ \\
\hline sOKT3 (10 ng/ml) & $2.2 \pm 0.3$ & $22.7 \pm 1.4$ & $22.4 \pm 4.3$ \\
\hline
\end{tabular}

${ }^{\text {aPBL }}$ were activated for 3 days by indicated mitogens. $\left[{ }^{3} \mathrm{H}\right] \mathrm{TdR}$ incorporation was measured during the last $8 \mathrm{~h}$ of culture. Dead cells were removed and ETO $(2 \mu \mathrm{M})$ or CPT $(1 \mu \mathrm{M})$ was added for $20 \mathrm{~h}$. Percentage of apoptotic cells, determined by fluorescent microscopy after staining with Hoechst 33342 , are expressed as mean \pm S.E.M. of three individual experiments
PHA plus CsA restores cell proliferation and sensitivity to topoisomerase inhibitors (data not shown).

\section{Etoposide and Camptothecin-induced apoptosis does not require CD95/CD95-L interaction}

In agreement with the above data we observed that maximal susceptibility of activated PBL to ETO and CPT was achieved after 3 days of activation and declined thereafter, following $\left[{ }^{3} \mathrm{H}\right] \mathrm{TdR}$ uptake kinetics (Figure 5A). Susceptibility to CD95mediated cell death followed different kinetic, increasing progressively up to day 5 (Figure 5A) as previously reported. $^{35-37}$ To further investigate the role of CD95/CD95$\mathrm{L}$ interaction in ETO- and CPT-induced apoptosis, we assessed CD95-L mRNA expression by RT-PCR. Treatment of activated PBL with ETO or CPT at 2 and $1 \mu \mathrm{M}$, respectively, significantly increased CD95-L mRNA expression only after $12 \mathrm{~h}$. Under the same conditions incubation of cells in the presence of PMA plus ionomycin showed an early peak at $6 \mathrm{~h}$ (Figure 6).

We next investigated whether ETO and CPT-induced apoptosis required CD95/CD95-L interaction. To this end, 3 day-PHA-activated $\mathrm{PBL}$ were preincubated for $1 \mathrm{~h}$ with blocking Fas-Fc fusion protein before addition of either ETO, CPT or CD95 agonistic mAb 7C11. Only apoptosis induced by the addition of 7C11 was blocked by the Fas-Fc fusion protein whereas ETO- and CPT-mediated apoptosis was not (Figure 5B). Further analysis on kinetics of ETO- or CPT-induced apoptosis in presence of FasFc showed that apoptosis was not delayed or diminished at any time of the kinetic (Figure 5C). Similar results were obtained with ZB4 or BD29, two antagonistic anti-CD95 mAbs used at 2 and

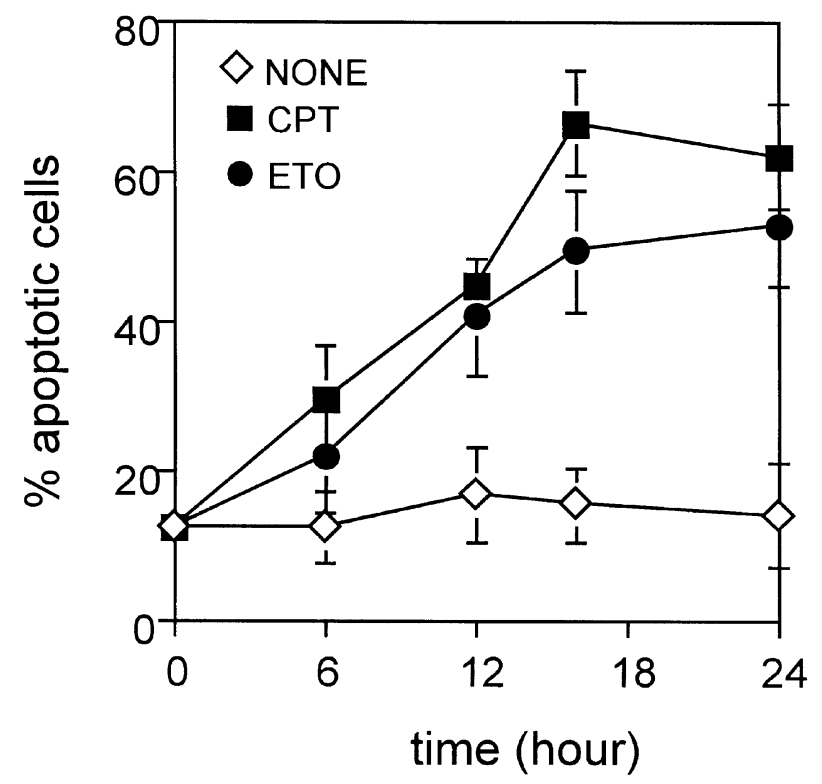

Figure 2 Kinetics of ETO- and CPT-induced apoptosis. PBL were cultured for 3 days with PHA $(5 \mu \mathrm{g} / \mathrm{ml})$. Dead cells were removed and medium, ETO $(2 \mu \mathrm{M})$ or CPT $(1 \mu \mathrm{M})$ were added to the cultures. Percentage of apoptotic cells was measured at the indicated time by Annexin $\mathrm{V}$ binding as described in Materials and Methods. Values are the mean \pm S.E.M. of three independent experiments 
$5 \mu \mathrm{g} / \mathrm{ml}$ respectively (data not shown). Finally because 3 day-PHA-activated PBL are not fully sensitive to CD95- mediated apoptosis we also tested whether CD95dependent mechanisms may contribute to ETO- and CPT-
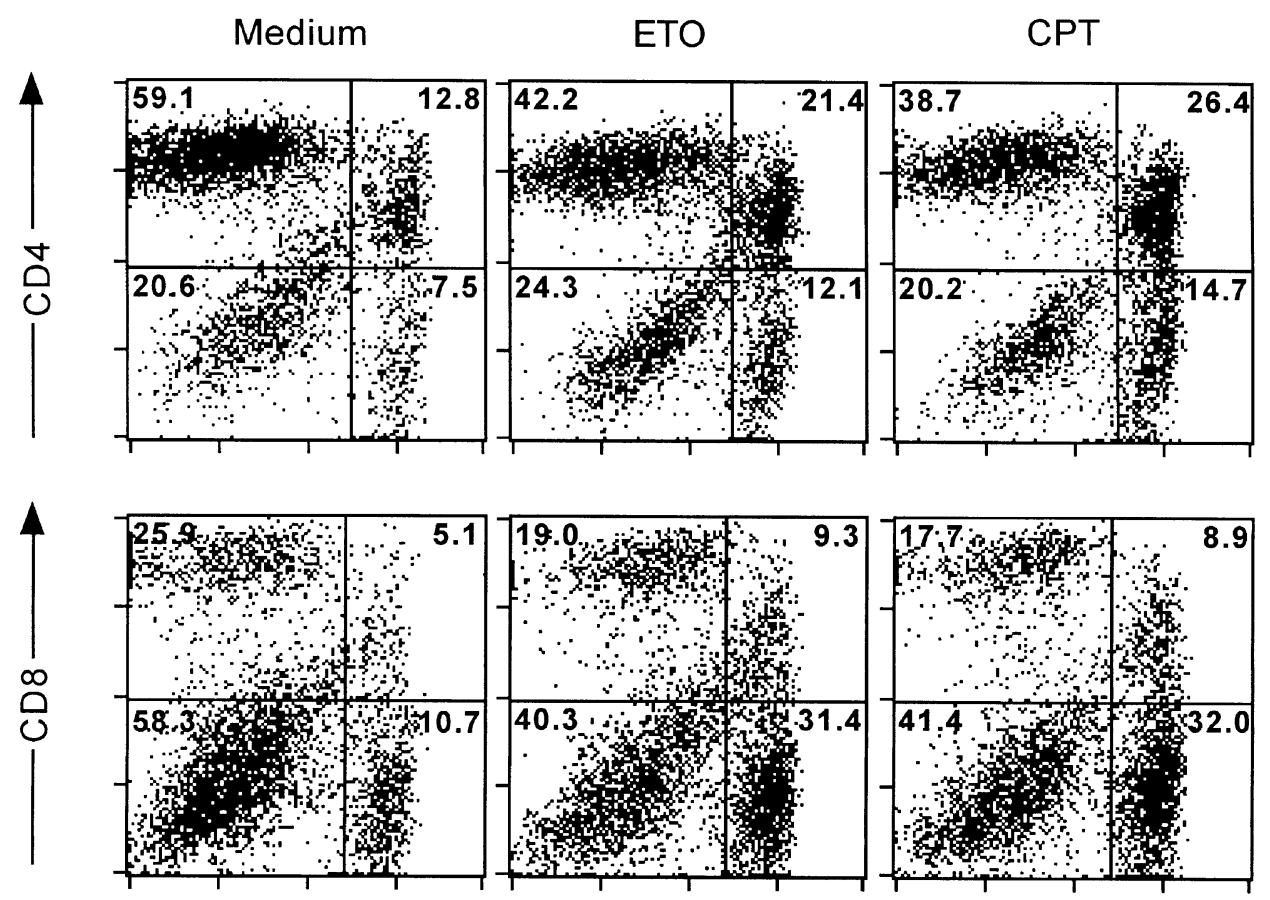

AnnexinV

Figure 3 ETO and CPT induced apoptosis of both $\mathrm{CD} 4^{+}$and CD8 ${ }^{+} \mathrm{PBL}$. Three-day-activated PBL were treated with ETO $(2 \mu \mathrm{M})$ or CPT $(1 \mu \mathrm{M})$ for $24 \mathrm{~h}$ then cells were stained with PE-anti-CD4 or -CD8 and expression of phosphatidylserine at the surface membrane was measured by FITC-conjugated Annexin V binding. Values shown on the figure are the percentage of the indicated cells. Results shown are representative of one among three experiments

A

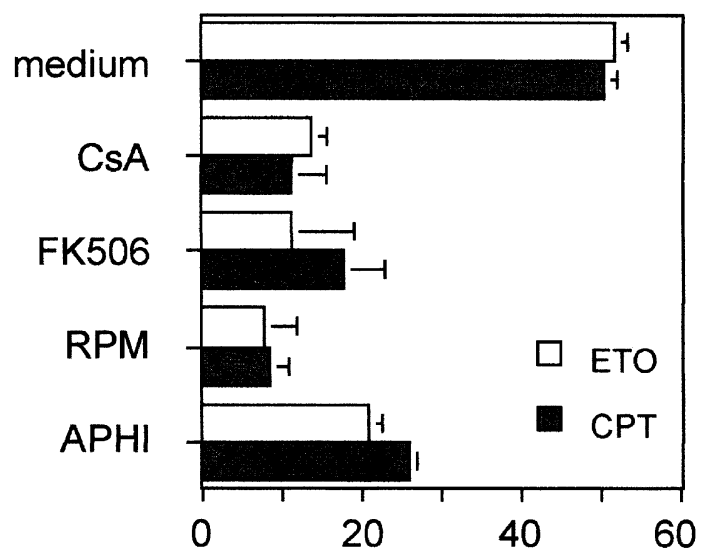

B

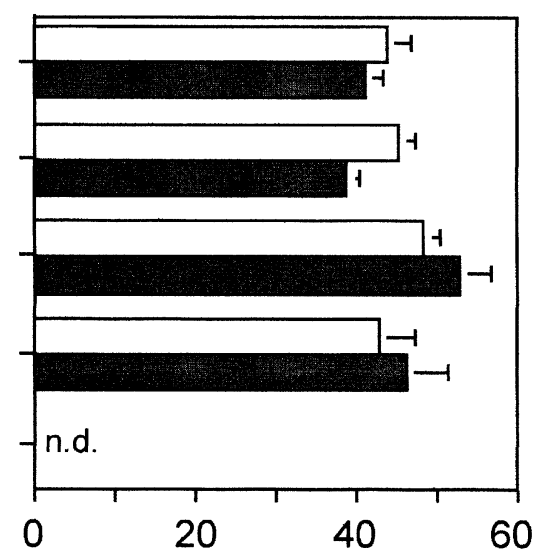

$\%$ specific apoptosis

Figure 4 Effect of inhibition of the G1 to S-phase transition on ETO- or CPT- induced apoptosis. (A) PBL were activated for 3 days with PHA (5 $\mu \mathrm{g} / \mathrm{ml})$ alone or in presence of CsA $(250 \mathrm{ng} / \mathrm{ml})$, FK506 $(10 \mathrm{nM})$, RPM $(60 \mathrm{nM})$ or aphidicolin $(125 \mathrm{ng} / \mathrm{ml})$. [ $\left.{ }^{3} \mathrm{H}\right] \mathrm{TdR}$ uptake, measured on the last $12 \mathrm{~h}$ of activation, was respectively 22609, 9948, 11043, 8365 and $9503 \mathrm{cpm}$. Seventy five \% of PHA-activated PBL expressed CD25, 58\% in presence of CsA, 62\% in presence of FK506, 79\% in presence of RPM and $55 \%$ in presence of aphidicolin. After removing dead cells, activated PBL were treated by ETO $(2 \mu \mathrm{M})$, or CPT $(1 \mu \mathrm{M})$ for $20 \mathrm{~h}$. Percentage of apoptotic cells was determined by fluorescent microscopy by Hoechst 33342 staining. Results are expressed as specific apoptosis as described in Materials and Methods. Values are the mean \pm S.E.M. of four (CsA, FK506 and RPM) or three (aphidicolin) individual experiments. (B) PBL were activated for 3 days with PHA $(5 \mu \mathrm{g} / \mathrm{ml})$. After removing dead cells, activated PBL were incubated for $4 \mathrm{~h}$ with CsA, FK506, RPM at the same concentrations as above then ETO $(2 \mu \mathrm{M})$, CPT $(1 \mu \mathrm{M})$ or medium were added for the next $20 \mathrm{~h}$. Percentage of apoptotic cells was determined as above. Values are the mean \pm S.E.M. of two individual experiments 
mediated apoptosis in 4-6 day PHA-activated PBL. As illustrated in Figure $5 \mathrm{~A}$ preincubation of activated $\mathrm{PBL}$ with the CD95 antagonist ZB4 never affected ETO- or CPTmediated apoptosis whereas it markedly reduced CD95induced apoptosis. Altogether these data indicate that despite the induction of CD95-L mRNA expression under ETO and CPT treatment, apoptosis of activated PBL induced by the two drugs does not require CD95/CD95L interaction. We also tested whether ETO- and CPTmediated apoptosis required $\mathrm{TNF} \alpha / \mathrm{TNFR}$ interaction.
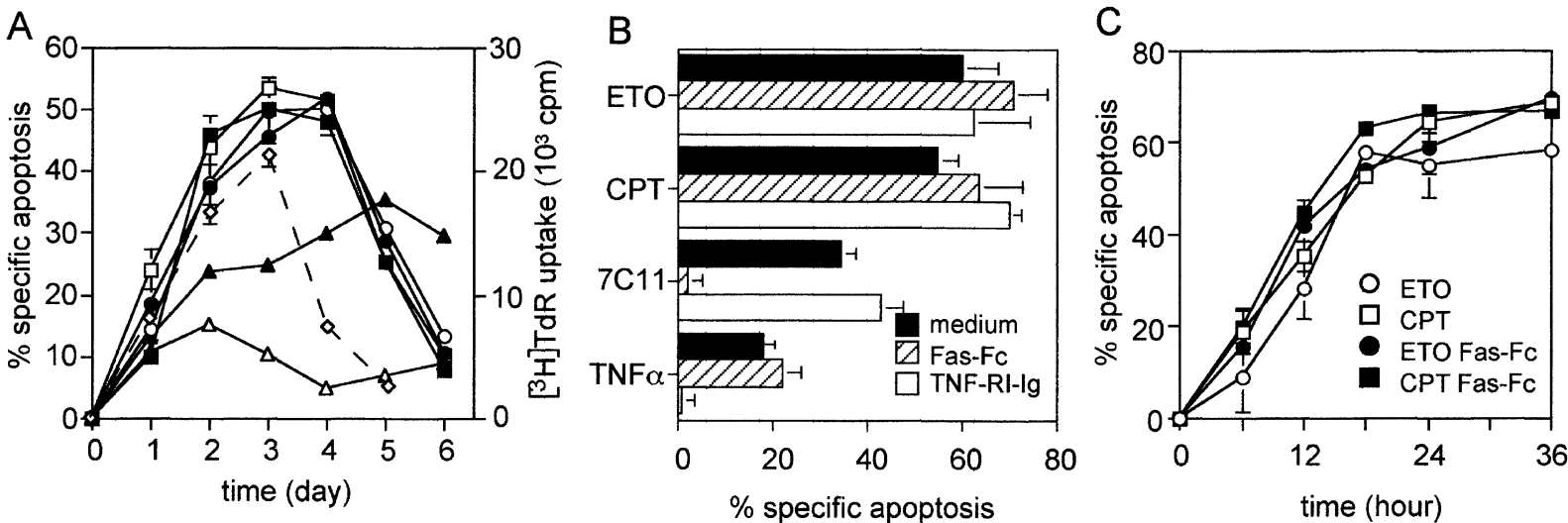

Figure 5 ETO- and CPT- induced apoptosis does not require CD95-CD95L interaction (A) Kinetics of sensitivity to ETO-, CPT- and CD95-mediated apoptosis PBL were cultured with PHA ( $5 \mu \mathrm{g} / \mathrm{ml})$. After 1, 2, 3, 4, 5 and 6 days of culture, viable cells were preincubated with CD95 antagonistic mAb ZB4 (opened symbols) or medium (closed symbols) for $2 \mathrm{~h}$, then cells were treated with ETO $(2 \mu \mathrm{M}$, circles), CPT ( $1 \mu \mathrm{M}$, squares), or the CD95 agonistic $\mathrm{mAb} 7 \mathrm{C} 11$ ( $1 \mu \mathrm{g} / \mathrm{ml}$, triangles) for $20 \mathrm{~h}$ and the percentage of specific apoptosis was determined by Annexin V binding as described in Materials and Methods. In parallel $\left.{ }^{3} \mathrm{H}\right] \mathrm{TdR}$ uptake during the last $8 \mathrm{~h}$ of culture was measured (dashed line). Values are the mean \pm S.E.M. of three individual experiments. (B) Lack of involvement of CD95/CD95-L and TNF $\alpha / T N F-R$ in ETO and CPT induced apoptosis. Three day-PHA-activated PBL were incubated with Fas-Fc $(20 \mu \mathrm{g} / \mathrm{ml})$ or TNF-R p55 lg $(20 \mu \mathrm{g} / \mathrm{ml})$ for $2 \mathrm{~h}$. Then ETO $(2 \mu \mathrm{M}), \mathrm{CPT}$ $(1 \mu \mathrm{M})$ or the CD95 agonistic mAb 7C11 $(1 \mu \mathrm{g} / \mathrm{ml})$ were added for $20 \mathrm{~h}$. Percentage of apoptotic cells was determined by fluorescent microscopy with Hoechst 33342. Results are expressed as specific apoptosis, as described in Materials and Methods. Values are the mean \pm S.E.M. of at three individual experiments. (C) Kinetics of ETO- and CPT-mediated apoptosis of Fas-Fc-preincubated PBL. Three day-PHA-activated PBL were incubated with Fas-Fc $(20 \mu \mathrm{g} / \mathrm{ml}$, open symbol) or none (closed symbol) for $2 \mathrm{~h}$ and ETO $(2 \mu \mathrm{M}$, circles) or CPT $(1 \mu \mathrm{M}$, squares) were added for the indicated time. The percentage of specific apoptosis was determined by fluorescence microscopy after staining with Hoechst 33342. Values are the mean \pm S.E.M. of two individual experiments
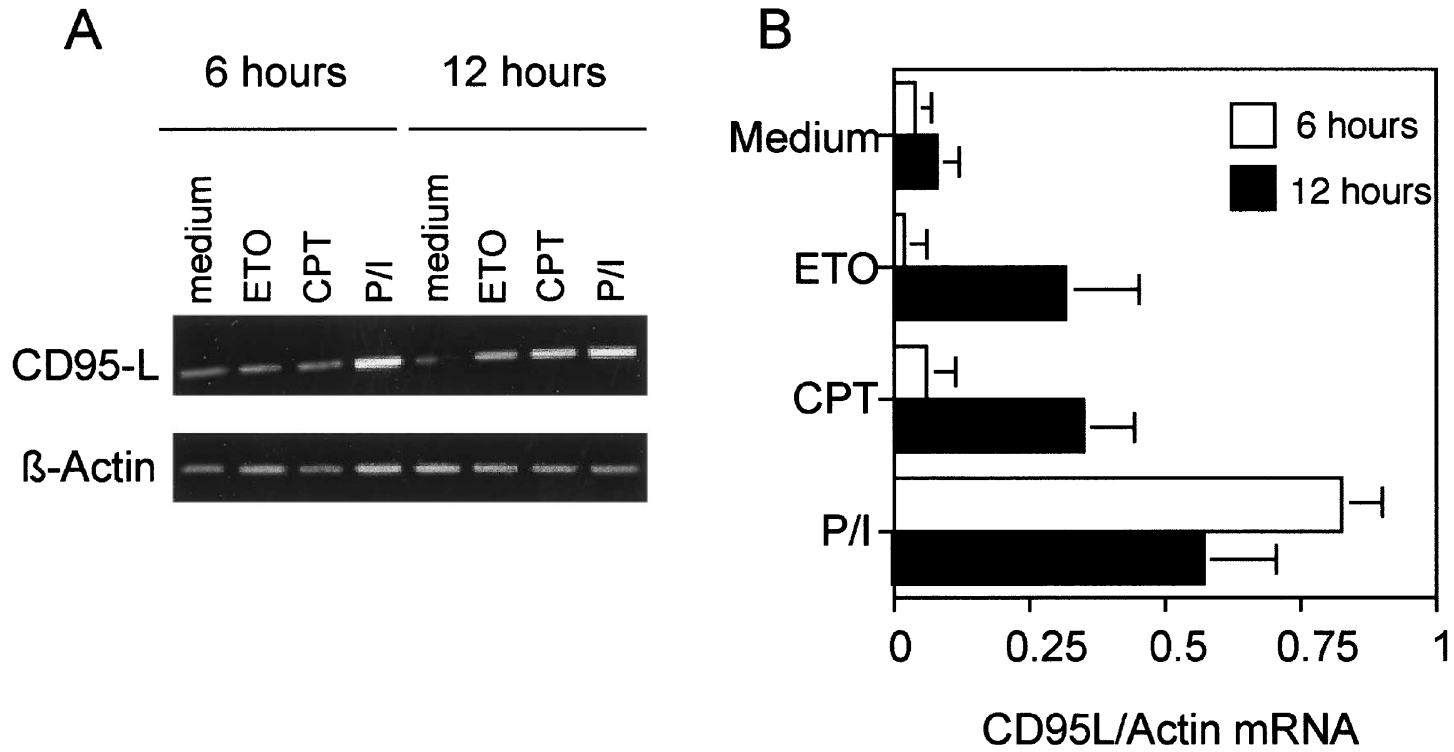

Figure 6 Expression of CD95-L mRNA induced by ETO or CPT. PBL were cultured in presence of PHA $(5 \mu \mathrm{g} / \mathrm{ml})$ for 3 days. Dead cells were removed and viable cells were incubated with ETO $(2 \mu \mathrm{M})$, CPT $(1 \mu \mathrm{M})$, PMA $(10 \mathrm{ng} / \mathrm{ml})$ plus ionomycin $(0.5 \mu \mathrm{g} / \mathrm{ml})$ or medium alone for 6 or $12 \mathrm{~h}$. mRNA of each sample was amplified by RT-PCR as described in Materials and Methods with primers specific for $\beta$-actin or CD95-L. (A) Data from a representative experiment among three showing similar results are shown. (B) The number of amplification selected within the exponential phase of PCR was 24 for actin and 35 for CD95-L.The PCR signal intensities were quantitated by scanning the negative film. Results are expressed as the ratio: CD95-L absorbance/Actin absorbance. Values are the mean \pm S.E.M. of three individual experiments 
Preincubation of activated PBL with soluble p55 TNFR-Ig did not affect ETO- and CPT-induced apoptosis whereas in the same conditions it completely inhibited apoptosis induced by TNF $\alpha$ (Figure 5B).

\section{Etoposide and Camptothecin-induced apoptosis requires caspase activation}

To further investigate ETO and CPT death signaling pathway in activated PBL, we tested whether activation of caspases was required. When 3-day-activated $\mathrm{PBL}$ were preincubated for 90 min in presence of zVAD-fmk at concentrations ranging from 1-100 $\mu \mathrm{M}$ before addition of ETO, CPT or 7C11 mAb, we observed a very efficient inhibition of CD95-mediated cell death at 10, 50 and $100 \mu \mathrm{M}$. Apoptosis induced by both ETO and CPT was only partially inhibited by zVAD-fmk, with $31-$ $51 \%$ inhibition at $50 \mu \mathrm{M}$ and $50-56 \%$ inhibition at $100 \mu \mathrm{M}$ (Figure 7). In order to clearly demonstrate caspase activation during apoptosis induced by ETO and CPT we tested the cleavage of the caspase 3 proenzyme as well as its substrate PARP. Caspase 3 underwent proteolytic processing from the $32 \mathrm{kDa}$ proform during ETO, CPT or anti-CD95 treatment of PHA-activated PBL. Decrease of the procaspase 3 band was detectable $6 \mathrm{~h}$ after addition of ETO or CPT (Figure 8). PARP was present as a full length protein of $116 \mathrm{kDa}$ in untreated cells. Processing of PARP into its $85 \mathrm{kDa}$ signature fragment was induced by CPT and ETO treatment after 2 or $6 \mathrm{~h}$ respectively (Figure 8 ) and by anti-CD95 treatment as previously reported. ${ }^{37}$ Induction of procaspase 3 and PARP cleavage by CPT and ETO but also by the anti-CD95

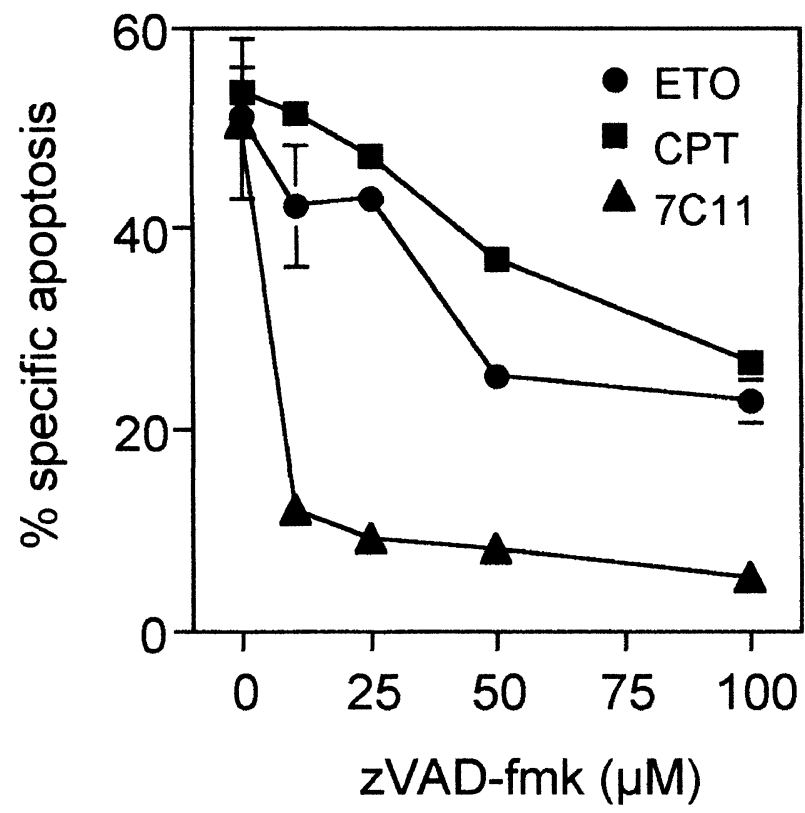

Figure 7 Involvement of caspases in ETO- or CPT- induced apoptosis. Three day-PHA activated PBL were incubated for $3 \mathrm{~h}$ in the presence of the tetrapeptide $z V A D$-fmk, in a dose range from 0 to $100 \mu \mathrm{M}$ before addition of ETO $(2 \mu \mathrm{M})$, CPT $(1 \mu \mathrm{M})$ or the CD95 agonistic mAb 7C11 $(1 \mu \mathrm{g} / \mathrm{ml})$. After $20 \mathrm{~h}$ percentage of apoptotic cells was determined by fluorescent microscopy after staining with Hoechst 33342 . Values are the mean \pm S.E.M. of three individual experiments agonistic mAb was restricted to PHA-blasts, which correlates with the observation that activated but not resting $\mathrm{PBL}$ are susceptible to ETO- CPT- and anti-CD95-induced apoptosis. The inhibitory peptide zVAD-fmk at $100 \mu \mathrm{M}$, which inhibited drug-induced apoptosis by about $50 \%$ (Figure 7) completely inhibited procaspase 3 and PARP cleavage (Figure 8).

\section{Etoposide and Camptothecin induce ceramide production in activated PBL}

Among recognized bioactive molecules in signal transduction, ceramide is a potent mediator of apoptosis induced by diverse chemotherapeutic agents in lymphoid and monocytic cell lines. ${ }^{25,27,28,30,39}$ We investigated whether CPT and ETO would induce ceramide production in PBL. Lipids were extracted from resting or 3-day-activated PBL treated with CPT or ETO, and endogenous production of ceramide was measured by a diacylglycerol kinase assay. As shown in Figure 9 we observed that both CPT and ETO induced a rapid increase in the level of ceramide in activated but not in resting PBL. Ceramide production after CPT treament was maximal after $60 \mathrm{~min}$ and decreased rapidly thereafter to reach the basal level after $2 \mathrm{~h}$. When cells were treated with ETO, maximal production was observed at $30 \mathrm{~min}$ (Figure 9).

\section{Discussion}

Previous studies have provided some evidence that apoptosis of leukemia cell lines, ${ }^{12,15}$ hepatoma cells ${ }^{4}$ as well as T cell hybridomas ${ }^{12}$ induced by chemotherapeutic agents such as CPT and ETO may proceed via a CD95/CD95-L dependent pathway in a manner analogous to activation-induced cell death. When used in cancer chemotherapy these agents may develop their cytotoxicity towards malignant cells as well as normal lymphocytes leading to deletion of activated tumorinfiltrating lymphocytes. The present study was therefore focussed on the effects of these compounds on resting and mitogen-activated PBL as a first simple assessment of drug cytotoxicity. We observed that CPT and ETO can induce apoptosis of both $\mathrm{CD}^{+}$or $\mathrm{CD}^{+}$activated but not resting PBL. CPT and ETO were previously described as $S$ and $G_{2} / M$ specific agents. ${ }^{5,40-42}$ However some reports demonstrated that CPT can also induce apoptosis in a cell-cycle independent fashion. ${ }^{7,43}$ Here we observed that induction of apoptosis by ETO and CPT is restricted to mitogen-activated PBL with a maximal percentage of apoptotic cells observed at 3 days of activation. Conversely, DNR which acts both as an intercalating agent and topoisomerase II inhibitor induced apoptosis of both resting and activated T cells. Accumulating cells in late $\mathrm{G} 1$ with aphidicolin or blocking $\mathrm{G}_{1}$ to $\mathrm{S}$-phase transition of the cell cycle by addition of CsA or FK506 which interfere with IL-2 gene transcription ${ }^{33}$ or RPM which inhibits IL-2 signaling ${ }^{34}$ protected cells from ETO- and CPT-mediated apoptosis, indicating that sensitivity of PBL to ETO and CPT requires $\mathrm{G}_{1}$ to $\mathrm{S}$-phase transition. Addition of CsA, FK506 or RPM to pre-activated PBL, just $4 \mathrm{~h}$ before treatment with either ETO or CPT, did not modify drug-induced apoptosis whereas such treatment almost completely reduced apoptosis induced by PMA associated to ionomycin $\left({ }^{44}\right.$ and our data not shown), suggesting that these immunosuppressive 
PBL PHA

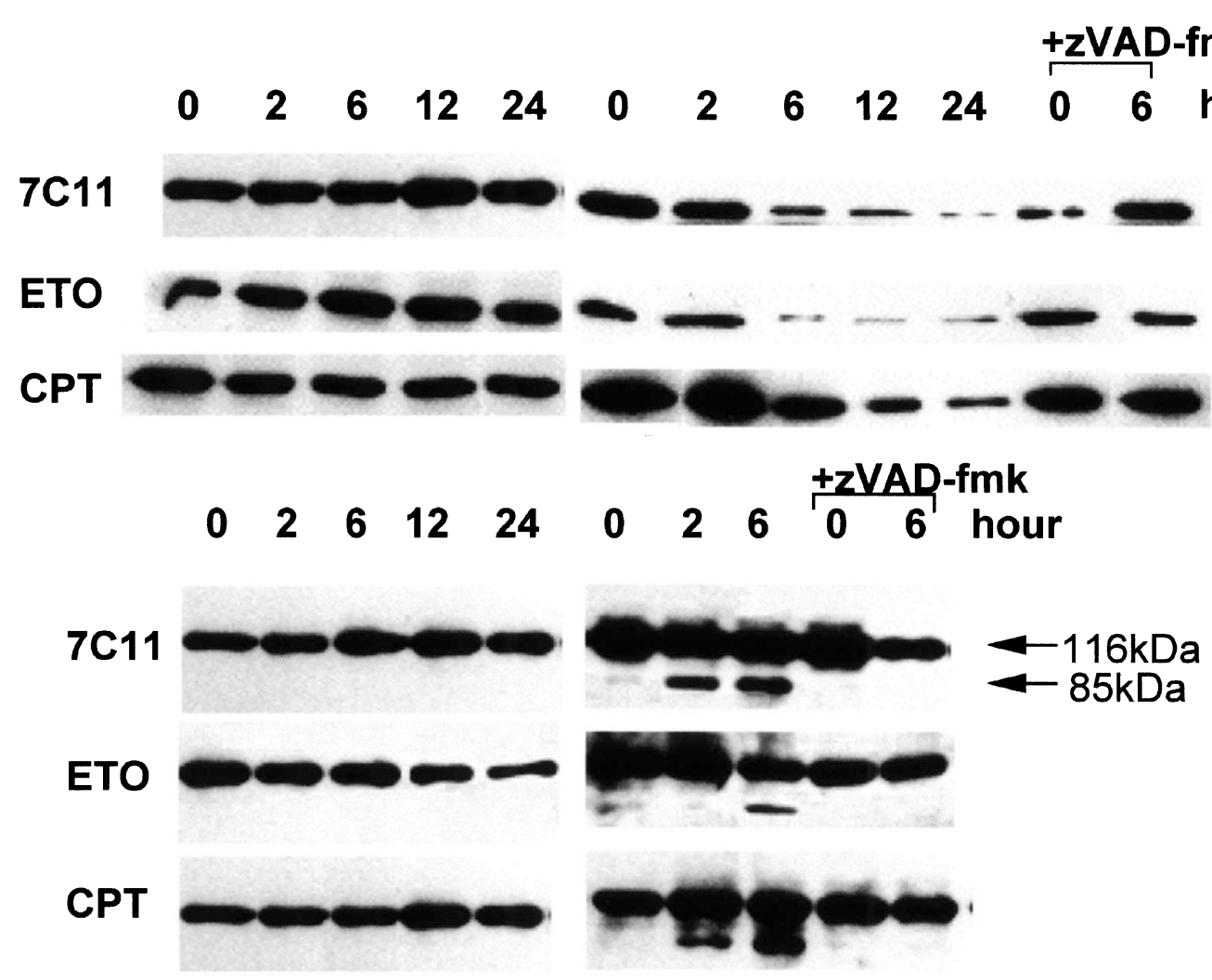

Figure 8 ETO and CPT induce caspase 3 and PARP cleavage. Freshly purified PBL or 3-day-PHA-activated PBL were treated for the indicated time with ETO $(2 \mu \mathrm{M})$, CPT $(1 \mu \mathrm{M})$ or the CD95 agonist mAb $7 \mathrm{C} 11(1 \mu \mathrm{g} / \mathrm{ml})$. PHA-activated PBL were also cultured $3 \mathrm{~h}$ in the presence of tetrapeptide $\mathrm{zVAD}$-fmk before being treated by ETO $(2 \mu \mathrm{M})$, CPT $(1 \mu \mathrm{M})$ or the CD95 agonist mAb $7 \mathrm{C} 11(1 \mu \mathrm{g} / \mathrm{ml})$ for $6 \mathrm{~h}$. Cell extracts were processed as described in Materials and Methods, subjected to SDS-PAGE, transferred to nitrocellulose, and probed with antibodies that recognize procaspase 3 (32 kDa) or PARP (116 kDa) and its signature fragment $(85 \mathrm{kDa})$

agents do not affect the signaling pathway triggered by ETO and CPT but rather prevent acquisition of susceptibility to ETO- and CPT-mediated cell death.

Involvement of CD95/CD95-L interaction in drug-induced apoptosis remains controversial. ${ }^{4,11,15}$ In our experiments, three different CD95 antagonists, Fas-Fc fusion protein and two mAb ZB4 and BD29 which all inhibit CD95-L-mediated cell death ( ${ }^{45}$ and Vermot-Desroches, unpublished data), did not exhibit any protective effect against ETO- or CPTinduced apoptosis of activated PBL which in the same experiments were shown to be fully sensitive to CD95mediated apoptosis. Furthermore, using soluble p55 TNF-R $\mathrm{Ig}$, we also eliminated the possibility that ETO and CPT can mediate apoptosis of activated PBL in a TNF-dependent pathway.

Interestingly we observed that the zVAD-fmk inhibitory peptide was about 10-50-fold more efficient in blocking CD95-mediated apoptosis as compared with drug-induced cell death, suggesting that requirement for caspases may be different in the two pathways. In agreement with previous reports in different experimental models ${ }^{19,46}$ our results indicate that ETO- or CPT- induced apoptosis of activated PBL may be in part independent of caspases activation. It was already reported that some death inducers, such anti-CD2 monoclonal antibodies, staurosporine as well as the pro-apoptotic protein Bax ${ }^{47,48}$ which induce caspase activation are however not blocked by the broad spectrum inhibitor zVAD. The tripeptide zVAD only prevented DNA fragmentation, a characteristic feature of apoptosis but not alterations in mitochondrial function, cell permeability and finally cell death. Similarly, cell permeable ceramides were also reported to induce cell death in a caspase independent fashion. ${ }^{49}$ Generation of ceramides has been already described with various chemotherapeutic agents. ${ }^{25,27,28,30,38,50}$ Here we report that ETO and CPT increased the generation of ceramide in sensitive (activated) but not in resistant (resting) PBL. Ceramide production was maximal after 30 and $60 \mathrm{~min}$ of treatment with ETO or CPT, respectively, corresponding to the earliest signal observed in ETO- and CPT- induced apoptosis. Indeed, generation of ceramide preceded activation of caspase 3 and PARP cleavage that occured $6 \mathrm{~h}$ after addition of the drugs. We previously observed that cell permeable ceramides can induce caspase activation, permeability transition and subsequent cell death of both resting and activated PBL. However mitochondrial dysfunc- 


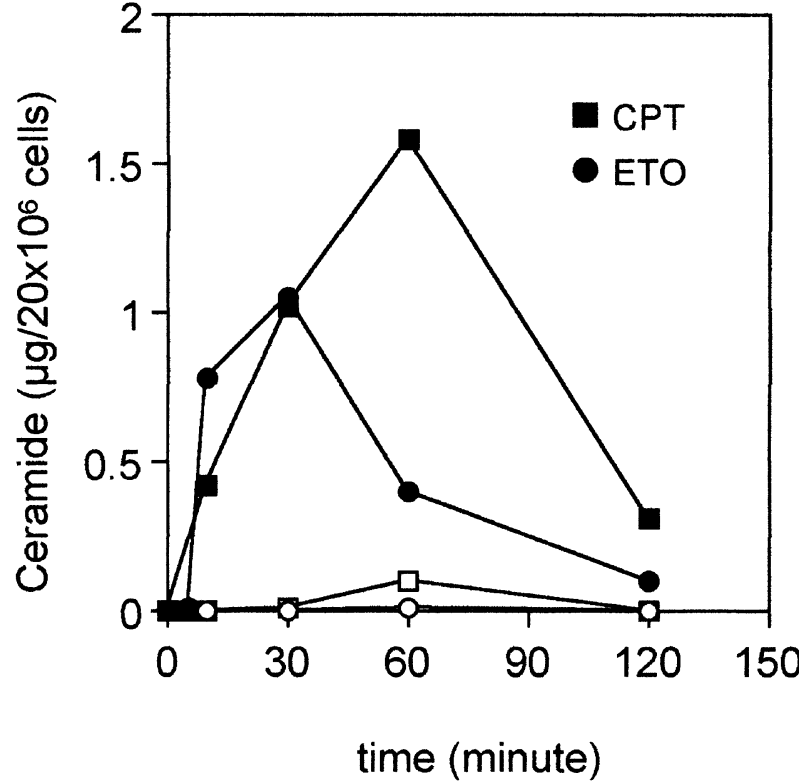

Figure 9 Time-course of ceramide production by ETO or CPT. Freshly purified PBL (open symbols) or 3-day-PHA-activated PBL $(5 \mu \mathrm{g} / \mathrm{ml}$, closed symbols) were incubated in the presence of medium alone, ETO $(2 \mu \mathrm{M})$ or CPT $(1 \mu \mathrm{M})$ for the indicated time. Quantification of ceramide production was performed by DAG-kinase assay after lipid extraction as described in Materials and Methods. Data from a representative experiment among three showing similar results are shown

tion and cell death were still observed in the presence of zVAD-fmk, despite decreased PARP cleavage ( ${ }^{38}$ and our unpublished data). So, in our model, the partial inhibition of apoptosis by zVAD-fmk can reflect the capacity of ceramide to alter mitochondrial dysfunction and to promote cell death in a caspase independent manner. The signals generated by DNA alterations that lead to ceramide production are still undefined. Ceramide has been recently demonstrated to be generated as a consequence of p53 activation during actinomycin D treatment of MOLT-4 cells. ${ }^{30}$ However ceramide production by activated $\mathrm{PBL}$ may not depend on p53 because Strasser et al. ${ }^{51}$ reported that $\gamma$-radiationinduced apoptosis of murine splenocytes was p53independent. Implication of other regulators of cellular response to DNA damage remains to be investigated.

Despite the demonstration that both CPT and ETO can induce apoptosis in a CD95/CD95-L-independent pathway, we observed a strong induction of CD95-L mRNA expression by these two drugs. However ETO- and CPTstimulated CD95-L mRNA expression showed a peak at $12 \mathrm{~h}$ which corresponds to delayed kinetics as compared with (i) that of CD95-L mRNA expression during activationinduced cell death of PBL triggered by PMA associated to ionomycin stimulation, and with (ii) the rapid kinetics of apoptosis (Figure 2) and caspase 3 activation that are observed after 2 and $6 \mathrm{~h}$ of exposure to CPT and ETO, respectively. Altogether these data suggest that the increase in CD95-L mRNA expression might not be relevant to ETO-and CPT-mediated apoptosis in $\mathrm{PBL}$, but rather reflect a secondary event of drug signaling in this cellular model. In agreement with this hypothesis, we observed that the addition of zVAD-fmk which partially inhibited apoptosis of PBL, did not decrease but rather sligthly increased CD95-L mRNA level in both ETO- and CPT-treated cells (data not shown) suggesting that upregulation of CD95-L mRNA is not directly linked to the capacity of these two drugs to induce cell death.

Finally our results suggest that the $T$ cell dependent immune responses that develop at the time of administration of these drugs may be impaired as a consequence of peripheral $\mathrm{T}$ cell clonal deletion, although such side effect remains limited to $T$ cells that undergo mitogenic activation.

\section{Materials and Methods}

\section{Cell preparation and culture}

PBL were collected from healthy donors in the presence of sodium citrate. Blood was defibrinated, then mononuclear cells were isolated by centrifugation on a layer of histopaque ${ }^{\circledR}$ (Dutcher, Brumath, France). Those cell suspensions referred to as PBL contained $1.8 \pm 0.4 \%$ monocytes and $4-11 \%$ B lymphocytes as defined by expression of CD14 and CD20, respectively. PBL were resuspended in RPMI 1640 (Sigma, St Louis, MO, USA) supplemented with 10\% fetal calf serum, $2 \mathrm{mM} \mathrm{L-glutamine,} \mathrm{and} \mathrm{antibiotics} \mathrm{(penicillin} 100 \mathrm{U} /$ $\mathrm{ml}$, Streptomycin $100 \mu \mathrm{g} / \mathrm{ml})$. Cells $\left(1 \times 10^{6} / \mathrm{ml}\right)$ were incubated in the presence of different mitogens. Cultures were maintained in a humid atmosphere containing $5 \% \mathrm{CO}_{2}$ for $72 \mathrm{~h}$. For proliferation assay cells were pulsed during the indicated time with (methyl ${ }^{3} \mathrm{H}$ ) thymidine $\left(\left[{ }^{3} \mathrm{H}\right] \mathrm{TdR}\right)$ (Amersham France SA, Les Ulis, France) at $0.5 \mu \mathrm{Ci} /$ well. $\left.{ }^{3} \mathrm{H}\right] \mathrm{TdRuptake}$ was measured using a Packard direct $\beta$ counter (Packard, Meriden, CT, USA) after harvesting.

\section{Antibodies and reagents}

A stock solution of ETO (kindly provided by Novartis, Basel, Switzerland) was prepared in ethanol at a concentration of $2 \mathrm{mM}$. CPT (Sigma, St Louis, MO, USA) was dissolved in DMSO at $20 \mathrm{mM}$. DNR was purchased from ICN biochemicals (Costa Mesa, CA, USA) and dissolved in distilled water. Different mitogens were used: PHA, PMA, ionomycin, SEB, Con A (Sigma), and the CD3 mAb OKT3 (Cilag Laboratories, Levallois Perret, France). CsA was kindly supplied by Novartis Corporation. FK506 and RPM were kindly supplied by Dr. Altman (La Jolla, CA, USA). Aphidicolin was purchased from Sigma. Fluorescein-isothiocyanate (FITC)-conjugated CD25 mAb or phycoerythrin (PE)-conjugated CD4 or CD8 mAbs were obtained from Becton Dickinson (Pont de claix, France). Purified anti-Fas mAb agonist (IgM, clone 7C11) and antagonist (IgG1, clone ZB4) were purchased from Immunotech (Marseille, France), the anti-Fas mAb antagonist BD29 was kindly provided by $\mathrm{C}$. Vermot-Desroches (Diaclone, Besançon, France). Fas-Fc fusion protein and TNF-R p55 Ig fusion protein were kindly provided by Dr. D. Green (La Jolla, CA, USA) and Dr. H. Waldman (Oxford, UK), respectively. TNF $\alpha$ was obtained from R\&D systems (Oxon, UK). The caspase inhibitory peptide zVAD-fmk was from Bachem (Voisins le Bretonneux, France).

\section{Measurement of apoptosis}

After 3 days of culture, PHA-activated PBL were harvested. Dead cells were removed by centrifugation on a layer of histopaque (Sigma) and washed in Hank's balanced salt solution. Viable cells $\left(10^{6} / \mathrm{ml}\right)$ were incubated in 96-well microplates with various drugs. After $20 \mathrm{~h}$ of incubation, cell death was evaluated by fluorescence microscopy after 
staining with Hoechst 33342 (Sigma) at $10 \mu \mathrm{g} / \mathrm{ml}$ following previously described methods. ${ }^{52}$ Nuclear fragmentation and/or marked condensation of the chromatin with reduction of nuclear size were considered as typical features of apoptotic cells. Based on these measurements, results were expressed as percentage of specific apoptosis according to the following formula:

$$
\% \text { specific apoptosis }=\frac{(\text { test control }) \times 100}{100 \text { control }}
$$

\section{Annexin V binding}

Exposure of surface phosphadidylserine was quantified by surface annexinV staining as described previously. ${ }^{53}$ Cells were resuspended in binding buffer and incubated with FITC-conjugated annexin V (Bender MedSystems, Austria) for $5 \mathrm{~min}$. Cells were analyzed by flow cytometry (Becton Dickinson; I. Ex. Max., 488 nM; I. Em. Max., $525 \mathrm{~nm}$ ) with the LYSYS II software.

\section{RNA isolation, reverse transcription, PCR amplification and quantification}

Total cellular RNA was isolated from 3 day-PHA activated PBL subsequently cultured for 6 or $12 \mathrm{~h}$ in presence or absence of ETO $(2 \mu \mathrm{M})$, CPT $(1 \mu \mathrm{M})$ or PMA $(10 \mathrm{ng} / \mathrm{ml})$ plus ionomycin $(0.5 \mu \mathrm{g} / \mathrm{ml})$. RNA was isolated by the method of Chomczynski and Sacchi. ${ }^{54}$ Reverse transcription and PCR was performed as previously described. ${ }^{55}$

\section{Determination of procaspase 3 and poly(ADP-ribose) polymerase (PARP) cleavage}

Cleavage of PARP and procaspase 3 was determined by Western blotting. Cells $\left(1 \times 10^{6}\right)$ were washed twice in phosphate buffered saline, pelleted, and lysed in $100 \mu$ l of lysis buffer containing $62.5 \mathrm{mM}$ Tris, $\mathrm{pH} 6.8,2 \%$ SDS, $10 \%$ glycerol, $2 \% \beta 2$-mercaptoethanol. After $10 \mathrm{~min}$ on ice, $20 \mu \mathrm{l}$ of $5 \times$ sample buffer were added, and samples were heated for $5 \mathrm{~min}$ at $95^{\circ} \mathrm{C}$. Thirty $\mu$ l of the lysate were subjected to $7.5 \%$ (PARP) or 15\% (procaspase 3) SDS-polyacrylamide gel electrophoresis gel and transferred to nitrocellulose membrane. Blots were probed using anti-PARP mAb C-2-10 (Biomol, TEBU, Le Perray en Yvelines, France) or anti-caspase $3 \mathrm{mAb}$ (Transduction Laboratories, Lexington, KY, USA). Bound antibodies were detected with rabbit anti-mouse peroxidase-conjugate (Biorad, Ivry sur Seine, France). An enhanced chemioluminescence system (Amersham), was used for detection.

\section{Ceramide measurement}

Ceramide was quantified by the diacyglycerol kinase assay as ${ }^{32} \mathrm{P}$ incorporated upon phosphorylation of ceramide to ceramide-1phosphate by diacylglycerol (DG) kinase from Eschericchia coli (Biomol, Plymouth Meeting, PA, USA) as previously described. ${ }^{50}$ Briefly, after 3 days of culture, $2 \times 10^{7} \mathrm{PBL}$ were starved for $2 \mathrm{~h}$ in RPMI containing $2 \%$ BSA and then treated with ETO, CPT or a CD95 agonistic $\mathrm{mAb}(7 \mathrm{C} 11)$ for indicated time. Ceramide-1-phosphate was resolved by $\mathrm{TLC}$ using $\mathrm{CHCl} / \mathrm{CH}_{3} \mathrm{OH} / \mathrm{CH}_{3} \mathrm{COOH}$ (65:15:5, vol/vol) as solvent. Authentic ceramide-1-phosphate was identified by autoradiography at $\mathrm{Rf} 0.25$. The level of ceramide was determined by comparison to concomitanly run standard curve comprised of known amounts of ceramide (Sigma) and normalized to $\left[{ }^{3} \mathrm{H}\right]$ triglyceryde introduced during lipid extraction.

\section{Acknowledgements}

We thank O. Assossou for expert assistance with RT-PCR. Research grant: This work was supported by Institut National de la Santé et de la Recherche Médicale, by Région Rhône Alpes Grant No. H098730000 (J.-P. Revillard), by Fondation pour la Recherche Médicale (J.-P. Revillard) and by Association pour la Recherche contre le Cancer Grant No 9607 (N. Bonnefoy-Berard). C. Ferraro is supported by an Association pour la Recherche contre le Cancer fellowship No CN1/98.

\section{References}

1. Hsiang YH, Lihou MG and Liu LF (1989) Arrest of replication forks by drugstabilized topoisomerase I-DNA cleavable complexes as a mechanism of cell killing by camptothecin. Cancer Res. 49: 5077-5082

2. Gorczyca W, Bigman K, Mittelman A, Ahmed T, Gong J, Melamed MR and Darzynkiewicz Z (1993) Induction of DNA strand breaks associated with apoptosis during treatment of leukemias. Leukemia 7: 659-670

3. Nicholson DW, Ali A, Thornberry NA, Vaillancourt JP, Ding CK, Gallant M, Gareau Y, Griffin PR, Labelle M, Lazebnik YA, Munday NA, Raju SM, Smulson ME, Yamin T, Yu VL and Miller DK (1995) Identification and inhibition of the ICE/ CED-3 protease necessary for mammalian apoptosis. Nature 376: 37-43

4. Muller M, Strand S, Hug H, Heinemann EM, Walczak H, Hofmann WJ, Stremmel W, Krammer PH and Galle PR (1997) Drug-induced apoptosis in hepatoma cells is mediated by the CD95 (APO- 1/Fas) receptor/ligand system and involves activation of wild-type p53. J. Clin. Invest. 99: 403-413

5. Goldwasser F, Shimizu T, Jackman J, Hoki Y, O'Connor PM, Kohn KW and Pommier $Y$ (1996) Correlations between $S$ and G2 arrest and the cytotoxicity of camptothecin in human colon carcinoma cells. Cancer Res. 56: 4430-4437

6. Fulda S, Sieverts H, Friesen C, Herr I and Debatin KM (1997) The CD95 (APO-1/ Fas) system mediates drug-induced apoptosis in neuroblastoma cells. Cancer Res. 57: 3823-3829

7. Morris EJ and Geller HM (1996) Induction of neuronal apoptosis by camptothecin, an inhibitor of DNA topoisomerase-l: evidence for cell cycleindependent toxicity. J. Cell. Biol. 134: 757-770

8. Shao RG, Cao CX and Pommier Y (1997) Activation of PKCalpha downstream from caspases during apoptosis induced by 7-hydroxystaurosporine or the topoisomerase inhibitors, camptothecin and etoposide, in human myeloid leukemia HL60 cells. J. Biol. Chem. 272: $31321-31325$

9. Pantazis P, Vardeman D, Mendoza J, Early J, Kozielski A, DeJesus A and Giovanella B (1995) Sensitivity of camptothecin-resistant human leukemia cells and tumors to anticancer drugs with diverse mechanisms of action. Leuk. Res. 19: $43-55$

10. Landowski TH, Gleason-Guzman MC and Dalton WS (1997) Selection for drug resistance results in resistance to Fas-mediated apoptosis. Blood 89: 1854 1861

11. Eischen CM, Kottke TJ, Martins LM, Basi GS, Tung JS, Earnshaw WC, Leibson PJ and Kaufmann SH (1997) Comparison of apoptosis in wild-type and Fasresistant cells: chemotherapy-induced apoptosis is not dependent on Fas/Fas ligand interactions. Blood 90: 935-943

12. Kasibhatla S, Brunner T, Genestier L, Echeverri F, Mahboubi A and Green DR (1998) DNA damaging agents induce expression of Fas ligand and subsequent apoptosis in T lymphocytes via the activation of NF-kappa B and AP-1. Mol. Cell $1: 543-551$

13. Hannun YA (1997) Apoptosis and the dilemma of cancer chemotherapy. Blood 89: $1845-1853$

14. Kollmannsberger C, Mross K, Jakob A, Kanz L and Bokemeyer C (1999) Topotecan-A novel topoisomerase I inhibitor: pharmacology and clinical experience. Oncology 56: 1-12

15. Friesen C, Herr I, Krammer PH and Debatin K-M (1996) Involvement of the CD95 (APO-1/Fas) receptor/ligand system in drug-induced apoptosis in leukemia cells. Nature Medicine 2: 574-577

16. Herr I, Wilhelm D, Bohler T, Angel P and Debatin KM (1997) Activation of CD95 (APO-1/Fas) signaling by ceramide mediates cancer therapy-induced apoptosis. EMBO J. 16: 6200-6208

17. McGahon AJ, Costa Pereira AP, Daly L and Cotter TG (1998) Chemotherapeutic drug-induced apoptosis in human leukaemic cells is independent of the Fas (APO-1/CD95) receptor/ligand system. Br. J. Haematol. 101: 539 
18. Villunger A, Egle A, Kos M, Hartmann BL, Geley S, Kofler R and Greil R (1997) Drug-induced apoptosis is associated with enhanced Fas (Apo-1/CD95) ligand expression but occurs independently of Fas (Apo-1/CD95) signaling in human Tacute lymphatic leukemia cells. Cancer Res. 57: 3331-3334

19. Tolomeo M, Dusonchet L, Meli M, Grimaudo S, D'alessandro N, Papoff G, Ruberti G and Rausa L (1998) The CD95/CD95L system is not the major effector in anticancer drug-mediated apoptosis. Cell death Differ. 5: 735-742

20. Obeid LM, Linardic CM, Karolak LA and Hannun YA (1993) Programmed cell death induced by ceramide. Science 259: 1769-1771

21. Cifone MG, Roncaioli P, De Maria R, Camarda G, Santoni A, Ruberti G and Testi R (1995) Multiple pathways originate at the Fas/APO-1 (CD95) receptor: sequential involvement of phosphatidylcholine-specific phospholipase $C$ and acidic sphingomyelinase in the propagation of the apoptotic signal. EMBO J. 14 5859-5868

22. Gulbins E, Bissonnette R, Mahboubi A, Martin S, Nishioka W, Brunner T, Baier G, Baier-Bitterlich G, Byrd C, Lang F, Kolesnick R, Altman A and Green D (1995) Fas-induced apoptosis is mediated via a ceramide-initiated Ras signaling pathway. Immunity 2: 341-351

23. Verheij M, Bose R, Lin XH, Yao B, Jarvis WD, Grant S, Birrer MJ, Szabo E, Zon LI, Kyriakis JM, Haimovitz-Friedman A, Fuks Z and Kolesnick RN (1996) Requirement for ceramide-initiated SAPK/JNK signalling in stress- induced apoptosis. Nature 380: 75-79

24. Jarvis WD, KolesnickRN, Fornari FA, TraylorRS, Gewirtz DA and GrantS (1994) Induction of apoptotic DNA damage and cell death by activation of the sphingomyelin pathway. Proc. Natl. Acad. Sci. USA 91: 73-77

25. Strum JC, Small GW, Pauig SB and Daniel LW (1994) 1-beta-DArabinofuranosylcytosine stimulates ceramide and diglyceride formation in HL-60 cells. J. Biol. Chem. 269: 15493-15497

26. Zhang Y, Yao B, Delikat S, Bayoumy S, Lin XH, Basu S, McGinley M, Chan-Hul PY, Lichenstein Hand Kolesnick R(1997) Kinase suppressor of Ras is ceramideactivated protein kinase. Cell 89: 63-72

27. Bose R, Verheij M, Haimovitz-Friedman A, Scotto K, Fuks Z and R K (1995) Ceramide synthase mediates daunorubicin-induced apoptosis: an alternative mechanism for generating death signals. Cell 82: 405-411

28. Jaffrezou JP, Levade T, Bettaieb A, Andrieu N, Bezombes C, Maestre N, Vermeersch S, Rousse A and Laurent G (1996) Daunorubicin-induced apoptosis: triggering of ceramide generation through sphingomyelin hydrolysis. EMBO J. 15: 2417-2424

29. Santana P, Pena LA, Haimovitz-Friedman A, Martin S, Green D, McLoughlin M, Cordon-Cardo C, Schuchman EH, Fuks Z and Kolesnick R (1996) Acid sphingomyelinase-deficient human lymphoblasts and mice are defective in radiation-induced apoptosis. Cell 86: $189-199$

30. Dbaibo GS, Pushkareva MY, Rachid RA, Alter N, Smyth MJ, Obeid LM and Hannun YA (1998) p53-dependent ceramide response to genotoxic stress. J. Clin. Invest. 102: 329-339

31. Laethem RM, Hannun YA, Jayadev S, Sexton CJ, Strum JC, Sundseth R and Smith GK (1998) Increases in neutral, Mg2+-dependent and acidic, Mg2+independent sphingomyelinase activities precede commitment to apoptosis and are not a consequence of caspase 3-like activity in Molt-4 cells in response to thymidylate synthase inhibition by GW1843. Blood 91: 4350-4360

32. Del Bino G, Skierski JS and Darzynkiewicz Z (1990) Diverse effects of camptothecin, an inhibitor of topoisomerase I, on the cell cycle of lymphocytic (L1210, MOLT-4) and myelogenous (HL-60, KG1) leukemic cells. Cancer Res. 50: $5746-5750$

33. Schreiber SL (1992) Immunophilin-sensitive protein phosphatase action in cell signaling pathways. Cell 70: $365-368$

34. Kuo CJ, Chung J, Fiorentino DF, Flanagan WM, Blenis J and Crabtree GR (1992) Rapamycin selectively inhibits interleukin-2 activation of p70 S6 kinase. Nature 358: $70-73$

35. Klas C, Debatin KM, Jonker R and Krammer P (1993) Activation interfers with the APO-1 pathway in mature human T cells. International Immunology 5: 625-630

36. Fournel S, Genestier L, Robinet E, Flacher M and Revillard JP (1996) Human T cells require IL-2 but not $\mathrm{G} 1 / \mathrm{S}$ transition to acquire susceptibility to Fas-mediated apoptosis. J. Immunol. 157: 4309-4315
37. Genestier L, Paillot R, Bonnefoy-Berard N, Meffre G, Flacher M, Fevre D, Liu YJ, Le Bouteiller P, Waldmann H, Engelhard VH, Banchereau J and Revillard JP (1997) Fas-independent apoptosis of activated T cells induced by antibodies to the HLA class I alpha1 domain. Blood 90: 3629-3639

38. Genestier L, Prigent AF, Paillot R, Quemeneur L, Durand I, Banchereau J, Revillard JP and Bonnefoy-Berard N (1998) Caspase-dependent ceramide production in Fas- and HLA class I-mediated peripheral T cell apoptosis. J. Biol. Chem. 273: 5060-5066

39. Hannun YA (1996) Functions of ceramide in coordinating cellular responses to stress. Science 274: 1855-1859

40. Johnson N, Ng TT and Parkin JM (1997) Camptothecin causes cell cycle perturbations within T-lymphoblastoid cells followed by dose dependent induction of apoptosis. Leuk. Res. 21: 961-972

41. Bruno S, Lassota P, Giaretti W and Darzynkiewicz Z (1992) Apoptosis of rat thymocytes triggered by prednisolone, camptothecin, or teniposide is selective to $\mathrm{G} 0$ cells and is prevented by inhibitors of proteases. Oncol. Res. 4: 29-35

42. Gorczyca W, Bruno S, Melamed MR and Darzynkiewicz Z (1992) Cell cyclerelated expression of $p 120$ nucleolar antigen in normal human lymphocytes and in cells of HL-60 and MOLT-4 leukemic lines: effects of methotrexate, camptothecin, and teniposide. Cancer Res. 52: 3491-3494

43. Cotter TG, Glynn JM, Echeverri F and Green DR (1992) The induction of apoptosis by chemotherapeutic agents occurs in all phases of the cell cycle. Anticancer Res. 12: 773-779

44. Alderson MR, Tough TW, Davis-Smith T, Braddy S, Falk B, Schooley KA, Goodwin RG, Smith CA, Ramsdell F and Lynch DH (1995) Fas ligand mediates activation-induced cell death in human T lymphocytes. J. Exp. Med. 181:71-77

45. Brunner T, Mogil RJ, LaFace D, Yoo NJ, Mahboubi A, Echeverri F, Martin SJ, Force WR, Lynch DH, Ware CF and Green DR (1995) Cell-autonomous Fas (CD95)/Fas-ligand interaction mediates activation- induced apoptosis in T-cell hybridomas. Nature 373: 441-444

46. Decaudin D, Geley S, Hirsch T, Castedo M, Marchetti P, Macho A, Kofler R and Kroemer G (1997) Bcl-2 and Bcl-XL antagonize the mitochondrial dysfunction preceding nuclear apoptosis induced by chemotherapeutic agents. Cancer Res. 57: $62-67$

47. Xiang J, Chao DT and Korsmeyer SJ (1996) BAX-induced cell death may not require interleukin 1 beta-converting enzyme-like proteases. Proc. Natl. Acad. Sci. USA 93: $14559-14563$

48. Deas O, Dumont C, MacFarlane M, Rouleau M, Hebib C, Harper F, Hirsch F, Charpentier B, Cohen GM and Senik A (1998) Caspase-independent cell death induced by anti-CD2 or staurosporine in activated human peripheral $\mathrm{T}$ lymphocytes. J. Immunol. 161: 3375-3383

49. De Maria R, Lenti L, Malisan F, d'Agostino F, Tomassini B, Zeuner A, Rippo MR and Testi $R$ (1997) Requirement for GD3 ganglioside in CD95- and ceramideinduced apoptosis. Science 277: 1652-1655

50. Mansat V, Bettaieb A, Levade T, Laurent G and Jaffrezou JP (1997) Serine protease inhibitors block neutral sphingomyelinase activation, ceramide generation, and apoptosis triggered by daunorubicin. FASEB J. 11: 695-702

51. Strasser A, Harris AW, Jacks T and Cory S (1994) DNA damage can induce apoptosis in proliferating lymphoid cells via p53- independent mechanisms inhibitable by Bcl-2. Cell 79: 329-339

52. Fournel S, Genestier L, Rouault JP, Lizard G, Flacher M, Assossou $O$ and Revillard JP (1995) Apoptosis without decrease of cell DNA content. FEBS Lett. 367: $188-192$

53. Koopman G, Reutelingsperger CP, Kuijten GA, Keehnen RM, Pals ST and van Oers MH (1994) Annexin V for flow cytometric detection of phosphatidylserine expression on B cells undergoing apoptosis. Blood 84: 1415-1420

54. Chomczynski Pand Sacchi N (1987) Single-step method of RNA isolation by acid guanidinium thiocyanate- phenol-chloroform extraction. Anal Biochem. 162: $156-159$

55. Genestier L, Fournel S, Flacher M, Assossou O, Revillard JP and BonnefoyBerard N (1998) Induction of Fas (Apo-1, CD95)-mediated apoptosis of activated lymphocytes by polyclonal antithymocyte globulins. Blood $91: 2360-2368$ 